\title{
Skolehage som arena for meningsfylt læring og utdanning for bærekraftig utvikling
}

\author{
Silje A. Wolff, Nasjonalt Senter for Realfagsrekruttering, NTNU og Unni Eikeseth, Institutt for \\ lærerutdanning, NTNU
}

\begin{abstract}
:
Elevers motivasjon for naturfag synker fra elever starter på skolen og gjennom barne- og ungdomsskolen. For norske ungdomsskoleelever er nedgangen særlig stor, og avstanden til de andre nordiske landene øker. Det er kjent at motivasjon er knyttet til en følelse av relevans, og flere studier tyder på at følelsesmessige sider av naturfaget blir forsømt i undervisning, slik som holdninger, motivasjon og interesse. Det er derfor behov for en naturfagundervisning som i større grad gir elever en opplevelse av det de lærer i naturfag er relevant for deres liv eller for samfunnet de lever i. Bærekraftig utvikling er et tema som engasjerer mange unge, og som derfor kan bidra til å gi økt relevans til naturfaget og andre fag. Det er også ett av tre tverrfaglige temaer i den nye læreplanen i norsk skole, Fagfornyelsen. Forskningen peker likevel på at det er fare for at bærekraftig utvikling blir forstått som et rent teoretisk spørsmål, uten at elever får høste konkrete erfaringer av hvordan bærekraftige liv kan leves gjennom handling. I denne studien undersøker vi skolehagens potensial for å øke motivasjon hos elever, samt egnethet som arena for utdanning for bærekraftig utvikling.
\end{abstract}

Med støtte i litteraturen finner vi grunn til å tro at skolehageaktiviteter kan bidra til opplevelse av økt relevans i naturfag, samt at skolehagen kan være en egnet arena for utdanning for bærekraftig utvikling.

\section{INTRODUKSJON}

Med innføring av den nye læreplanen Fagfornyelsen, LK20, og en uttrykt målsetting om mer praktisk og utforskende undervisning, trengs nye arenaer for å kombinere teori og praksis gjennom oppgaver som oppleves meningsfulle og relevante for elevene. Mange unge sliter med motivasjonen for det faglige fordi de ikke opplever fagene som relevante i deres liv. Den internasjonale TIMSS-studien viser blant annet at elever kommer til skolen med en sterk motivasjon for å lære naturfag, men at denne motivasjonen synker gjennom barneskolen og ungdomsskolen (Mullis, Martin, Foy, Kelly \& Fishbein, 2020). I følge Ryan og Deci (2000) utløses indre motivasjon gjennom tilfredsstillelse av grunnleggende behov for selvbestemmelse, og opplevelse av kompetanse gjennom mestring, tilknytning og tilhørighet. I utdanning har disse behovene blitt utvidet med tre tilleggsfaktorer; oppfattelse av relevans, hvor engasjert læreren er, og hvor god instruksjonen er (Prenzel, 1997). Antonovsky (2012) understreker at opplevelse av følelsesmessig mening påkaller mennesker til å ville forbinde seg med og å utføre oppgaver. I følge Antonovsky bygger læringsoppgaver som kjennetegnes av følelsesmessig meningsfullhet, forståelse og håndterbarhet elevenes opplevelse av sammenheng (Jensen og Johnsen 2000). Opplevelser og praktiske erfaringer tilegnet i en skolehage kan $\varnothing$ ke elevens bevissthet og kunnskap om bl. a. kosthold og egen helse, og kan også å ha en positiv effekt på psykisk velvære hos barn og unge (Lam et al. 2019). Læringsutbytte og pedagogisk grunnlag for skolehager til barn i barnehage og grunnskole er veldokumentert (Hugo, 2000; Jolly og Leisner, 2012), men har også et stort potensial som læringsarena for eldre elever og studenter.

Bærekraftig utvikling er videreført som et viktig element i Fagfornyelsen, og har fått status som ett av tre tverrfaglige temaer. Stortingsmeldingen Fremtidens skole beskriver at opplæringen skal bidra til at elevene laerer å tenke kritisk og handle etisk og miljøbevisst (NOU, 2015). Ifølge forskerne Sinnes og Straume (2017) er det imidlertid fare for at bærekraftproblematikken i Fagfornyelsen fortsatt blir redusert til et kognitivt spørsmål som elevene skal forstå, men uten at elevene får tilstrekkelige redskaper for å omsette kunnskap til handling for en mer bærekraftig utvikling. De etterlyser at elevene i skolehverdagen får høste flere konkrete erfaringer av hvordan bærekraftige liv kan leves gjennom 
handlinger. Det er derfor viktig å utdanne lærere som kan bidra til å gi elever handlingskompetanse i bærekraft.

I denne artikkelen ønsker vi å undersøke følgende spørsmål;

- Hvordan kan skolehageaktiviteter bidra til relevant og meningsfylt undervisning i naturfag?

- På hvilken måte kan skolehagen bidra til økt bærekraft-kompetanse?

\section{BAKGRUNN}

\subsection{Motivasjon og interesse i naturfagundervisning}

Flere studier har påpekt naturfagundervisningens forsømmelse av ulike affektive aspekter, slik som følelser, holdninger, motivasjon eller interesse (f.eks Alsop \& Watts, 2003; Osborne, Simon \& Collins, 2003). Ulike tilnærminger har blitt fors $\varnothing \mathrm{kt}$ for å gjøre naturfagundervisningen mer interessant og relevant for elever, som blant annet kontekstbasert undervisning. En kontekst kan forstås som en situasjon som bidrar til å kommunisere mening til en elev (De Jong \& Taber, 2014). En del studier tyder på at kontekstbaserte tilnærminger til læring har positive effekter på elevers interesse (blant annet Bennett, Lubben \& Hogarth, 2007). En opplevelse av relevans er sett på som særlig viktig i kontekstbasert undervisning, og kontekster som har personlig relevans er funnet å være mest positive for elevers motivasjon og interesse (Menthe \& Parchmann, 2015). Det britiske undervisningsprosjektet The Science Capital Teaching Approach bygger på å ta utgangspunkt i elevens interesser og erfaringer. Denne undervisningstilnærmingen har vist seg å være effektiv for å $\emptyset$ ke elevers engasjement i naturfag (Godec, King \& Archer, 2017). Erfaringsbasert læring og aktualisering av naturfaget gjennom en undervisning som elevene opplever som relevant for livet også utenfor og etter skolen, ble gjennom en studie funnet å øke motivasjonen også blant norske elever (Knain og Kolstø, 2011).

\subsection{Utdanning for bærekraftig utvikling}

Begrepet bærekraft er blitt et nøkkelord både for samfunnet og utdanningsinstitusjoner. Bærekraftig utvikling ble definert i Brundtlandrapporten som en utvikling som ivaretar dagens behov uten å $\phi$ delegge mulighetene for at kommende generasjoner skal få dekket sine behov (Verdenskommisjonen for miljø og utvikling, 1987, s. 42). Ifølge Sinnes og Straume (2017) har bærekraftig utvikling som tema vært til stede i norsk utdanningspolitikk siden begynnelsen av 1970-tallet. Deres gjennomgang av studier av utdanning for bærekraftig utvikling (UBU) i norsk skole til nå tyder imidlertid på at formuleringer i styringsdokumenter ikke har ført til de endringene i skolens praksis som dagens miljøutfordringer skulle tilsi. I stedet er UBU i Norge fragmentert og lite helhetlig, og oppleves som svært læreravhengig og lite forpliktende for mange lærerene.

Basert på en litteraturgjennomgang fant Hedefalk, Almqvist og Östman (2014) to ulike definisjoner for UBU; den ene handler om utdanning OM, I og FOR miljøet. UNESCO (2014) har videre pekt på at skolen i seg selv må være et sted hvor elevene kan lære å leve bærekraftige liv, det vil si skolen SOM arena for bærekraftig utvikling. Den andre definisjonen som Hedefalk et al. fant handler om de $\emptyset$ konomiske, sosiale og miljømessige dimensjonene ved bærekraftig utvikling. Disse tre dimensjonene er vevd inn i hverandre, noe som understreker at menneskers livsstil, natur og samfunn virker inn på hverandre.

Sinnes (2015) beskriver følgende fire kjerneelementer som er sentrale for utdanning for bærekraftig utvikling;

1. Faglig oppdatert kunnskap knyttet til klima og barekraft

2. Tverrfaglig tilnarming til undervisningen

3. Vekt på å utvikle andre kompetanser enn de rent teoretiske, slik som kreativitet, kritisk tenkning, systemforståelse, kommunikasjon og samarbeidsevner, fremtidstenkning og fremtidstro, handlingskompetanse og å kunne ha det godt med et mindre forbruk.

4. Skolen må vare en arena for å lare å leve på en barekraftig måte. 
Handlingskompetanse er blant annet viktig for å unngå at unge mennesker blir handlingslammet på grunn av den kognitive konflikten mellom kunnskap om problemet og hva de faktisk gjør (Sinnes, 2020), Det er derfor viktig at skolen hjelper elever til å finne måter de kan bidra til endring på.

\section{DISKUSJON}

I denne delen vil vi svare på de to forskningsspørsmålene ved å diskutere hvordan skolehageaktiviteter kan bidra til en mer meningsfylt og motiverende naturfagundervisning, og på hvilken måte skolehagen kan bidra til utdanning for bærekraftig utvikling.

\subsection{Skolehage for økt motivasjon og meningsfylt undervisning}

I en skolehage er det rike muligheter for å utforske mange ulike temaer. Karbonbinding i jord og plantemateriale (Jones, 2008), ressursgjenvinning og mer bærekraftige metoder for matproduksjon (Pfeiffer, 2003) er bare noen eksempler på dagsaktuelle temaer på tvers av fag som kan belyses gjennom en undervisningshage. Hagen kan også være en «sandkasse» for utprøving og erfaringslæring knyttet til bruk av sensor- og måleteknologi fra ulike industrier og produksjonsanlegg. På denne måten kan skolehagen fungere som en kontekst som kan bidra til å gi mening til faglig læring. I tråd med funnene fra kontekstbasert naturfagundervisning er det derfor grunn til å tro at skolehageaktiviteter kan bidra til å fremme motivasjon og interesse hos elevene. En skolehage er, slik vi ser det, en velegnet arena for erfaringslæring som oppleves meningsfull og øker motivasjonen for naturfag. Ved å dyrke og følge en plante over tid får begreper som rot, stengel og blad, eller blomst, frukt og frø et helt reelt innhold og mening (Hugo, 2000). En gjennomgang av 48 studier om skolehagers betydning for faglig forståelse fant at skolehagebasert-læring hadde positiv innvirkning på elevers karakterer, kunnskap, holdninger og oppførsel i naturfag og matematikk, men også fag som språk og kunst (Williams \& Dixon, 2013). Funnene var positive for alle aldersgrupper av elever. Skolehageprogrammene som var inkludert i studien hadde mange ulike formål, men flere av programmene la vekt på å øke relevansen i ulike disiplinfag, og da særlig naturfag gjennom blant annet læring gjennom praktiske oppgaver, og å utvikle bærekraftig forvaltning.

\subsection{Skolehage som arena for bærekraftig utvikling}

Gjennom aktiviteter i en skolehage kan elever få praktisk erfaring med å så frø og dyrke og høste mat. De kan også legge til rette for biologisk mangfold ved å lage insekthotell og plante insektvennlige blomster. Sinnes (2015) peker på at å kunne lære om mat og matsikkerhet gjennom selv å dyrke mat gir elevene førstehåndsopplevelser og erfaringer som de ikke kan få gjennom teori. Særlig stort læringsutbytte kan det være dersom man kombinerer skolehagen med kompostering og matlaging. Undervisning i en skolehage burde gi rike muligheter for å oppfylle alle de fire kjerneelementene for UBU. Som alt har vært diskutert i 3.1. kan skolehagen fungere som en kontekst for å lære om fag, deriblant tema som klima og bærekraft. Å knytte undervisningen til kontekst er viktig i en utdanning for bærekraftig utvikling (Sinnes, 2015). I tillegg kan skolehagen gi mulighet for tverrfaglig samarbeid mellom naturfagene og fag som for eksempel kunst og håndverk og mat og helse (Sinnes, 2015). Skolehageaktiviteter kan videre være med på å utvikle andre kompetanser enn de rent teoretiske, deriblant kreativitet og handlingskompetanse. Til sist kan skolehagen bidra til at skolen går fram som et godt eksempel for en bærekraftig livsstil.

Vi har funnet få studier som har undersøkt betydningen av skolehage for utdanning for bærekraftig utvikling, og disse er heller ikke entydig positive når det gjelder om skolehagebasert læring kan føre til $\emptyset \mathrm{kt}$ bærekraftkompetanse. I en gjennomgang av amerikanske skolehageinitiativ fant Blair (2009) ingen effekt på elevers sosiale oppførsel eller holdninger til miljø gjennom publiserte studier. Arbeidet avdekket også et behov for opplæring i bruk av skolehage som læringsarena i lærerutdanningen. En masteroppgave fra Lehrmann (2020) fant også at norske lærere uttrykker behov for kunnskaper og praktiske erfaringer med bruk av skolehage i undervisning. Basert på intervjuer med interessenter involvert i prosjektering av en skolehage fant Cheang, So, Zhan og Tsoi (2016) at en skolehage kan være et kraftfullt læringsmiljø for å tilegne seg kunnskaper om bærekraftig utvikling, men deres studie har ikke unders $\varnothing \mathrm{kt}$ faktisk oppnådd kompetanse. 


\section{OPPSUMMERING}

Vår gjennomgang av forskning tyder på at skolehageaktiviteter kan bidra positivt til økt motivasjon og mening i naturfagundervisningen. Ved å bruke skolehage som arena for praktiske erfaringer og faglig læring, kan elever oppleve naturfag som mer relevant enn ved tradisjonell klasseromsundervisning. Når det gjelder utdanning for bærekraftig utvikling, finner vi at muligheter ligger til rette for at skolehager kan bidra til økt kompetanse for bærekraftig utvikling ved å være egnet for å gi faglig undervisning $\mathrm{i}$ en relevant kontekst, være tilrettelagt for tverrfaglig undervisning, ved at elever kan utvikle andre ferdigheter enn de rent teoretiske, og at skolen kan gå fram som et godt eksempel på bærekraftig livsstil ved å anlegge en skolehage. Tilknytningen til skolehagen og mestring av disse kompetansene kan fremme motivasjonen for å tenke og handle bærekraftig. Det er likevel behov for mer forskning for å unders $\emptyset \mathrm{ke}$ om skolehageaktiviteter faktisk kan føre til $\varnothing \mathrm{kt}$ bærekraftkompetanse. For å bidra til mer kunnskap om dette, og gi flere lærere erfaring med skolehagen som læringsarena, planlegger vi oppbygging av en skolehage ved en norsk lærerutdanningsinstitusjon. I framtiden $\emptyset$ nsker vi å unders $\emptyset$ ke i hvilken grad skolehagebasert læring kan bidra til bærekraftkompetanse hos lærerstudenter, samt på hvilken måte skolehagen kan gjøre lærerstudenter trygge på selv å undervise om bærekraft i en skolehagesetting.

\section{REFERENCES}

Alsop, S., \& Watts, M. (2003). Science education and affect. International Journal of Science Education, 25(9), 1043-1047.

Antonovsky, A. (2012). Helsens mysterium. Den salutogene modellen. Oslo: Gyldendal Akademisk

Bennett, J., Lubben, F. \& Hogarth, S. (2007). Bringing science to life: A synthesis of the research evidence on the effects of context-based and STS approaches to science teaching. Science Education (Salem, Mass.), 91(3), $347-370$.

Cheang, C.C., So, W.-M. W., Zhan, Y. \& Tsoi, K. H. (2016) Education for sustainability using a campus ecogarden as a learning environment. International Journal of Sustainability in Higher Education, 18(2), 242262.

De Jong, O. \& Taber, K. S. (2014) The Many Faces of High School Chemistry. In S. K. Abell; N. G. Lederman, Handbook of Research on Science Education, Volume II (pp. 471-494). Routledge.

Godec, S., King, H. \& Archer, L. (2017) The Science Capital Teaching Approach: engaging students with science, promoting social justice. London: University College London

Hedefalk, M., Almqvist, J., \& Östman, L. (2015). Education for sustainable development in early childhood education: A review of the research literature. Environmental Education Research, 21(7), 975-990.

Hugo, A. (2000). A ta skrittet ut - utearealet som læringsarena. Rapport fra prosjektet levande skule.

Jensen, T. K. og T. J. Johnsen (2000). Sundhetsfremme i Teori og praksis. Århus, Philosophia, 86-91.

Jolly, L. og Leisner, M. (2000). Skolehagen - Etablering, drift og pedagogisk tilrettelegging av en skolehage, Landbruksforlaget, Oslo.

Jones, C. (2008), Liquid Carbon Pathway, Extract from Australian Farm Journal 338 https://www.amazingcarbon.com/PDF/JONES-LiquidCarbonPathway(July08).pdf

Knain, E. \& Kolstø, S. D. (2011). Naturfag - uenighet og tvil som grunnlag for læring. Bedre Skole 4/ 2011.

Lam, V, Romses, K., \& Renwick, K. (2019). Exploring the Relationship between School Gardens, Food Literacy and Mental Well-Being in Youths Using Photovoice. Nutrients, 11(6), 1354.

Lehrmann, M. (2020). Skolehagen som en realisering av utdanning for barekraftig utvikling - hvordan legge til rette for en motiverende skolehageundervisning på skolen? Mastergradsoppgave Lektorutdanning i realfag. Seksjon for læring og lærerutdanning, Fakultet for realfag og teknologi, Norges miljø- og biovitenskapelige universitet, $\AA$ s

Menthe, Jürgen, \& Parchmann, Ilka. (2014). Getting Involved: Context-Based Learning in Chemistry Education. In M. Kahveci \& M. Orcill (Eds) Affective Dimensions in Chemistry Education (pp. 51-67). Berlin, Heidelberg: Springer Berlin Heidelberg.

Mullis, I. V. S., Martin, M. O., Foy, P., Kelly, D. L., \& Fishbein, B. (2020). TIMSS 2019 International Results in Mathematics and Science. Retrieved from Boston College, TIMSS \& PIRLS International Study Center. https://timssandpirls.bc.edu/timss2019/international-results/

NOU (2015: 8). Fremtidens skole - Fornyelse av fag og kompetanser. Hentet 3/1/2021 fra https://www.regjeringen.no/contentassets/da148fec8c4a4ab88daa8b677a700292/no/pdfs/nou201520150008 000dddpdfs.pdf 
Osborne, J., Simon, S., \& Collins, S. (2003). Attitudes towards science: A review of the literature and its implications. International Journal of Science Education, 25(9), 1049-1079.

Pfeiffer, D. A. (2003), Eating Fossil Fuels. Tilgjengelig fra https://www.resilience.org/stories/2003-10-02/eatingfossil-fuels/

Prenzel, M. (1997) Sechs Möglichkeiten Lernende zu demotivieren. Wege zum Können. In H. Gruber \& A. Renkl. (Red.) Determinanten des Kompetenzerwerbs (s. 32-44). Bern, Sveits: Huber.

Ryan, R.M. and Deci, E.L (2000). Self-Determination Theory and the Facilitation of Intrinsic Motivation, Social Development, and Well-Being. American Psychologist 55(1), 68-78.

Sinnes, A. (2015). Utdanning for barekraftig utvikling: Hva, hvorfor og hvordan? Oslo: Universitetsforlaget.

Sinnes, A. (2020). Action, takk! : Hva kan skolen lære av unge menneskers handlinger for bærekraftig utvikling? (1. utgave. ed.). Oslo: Gyldendal.

Sinnes, A. T., \& Straume, I. S. (2017). Bærekraftig utvikling, tverrfaglighet og dybdelæring: Fra big ideas til store spørsmål. Acta Didactica Norge, 11(3), 7.

UNESCO (2014). Shaping the future we want. UN Decade of Education for Sustainable Development (20052014). final Report.

Verdenskommisjonen for miljø og utvikling (1987). Vår felles framtid. Oslo: Tiden Norsk Forlag

Williams, D.R. and Dixon, P.S. (2013), Impact of garden-based learning on academic outcomes in schools: synthesis of research between 1990 and 2010. Review of Educational Research, Vol. 83 (2), 211-235. 